Journal of Social Sciences 8 (2): 267-273, 2012

ISSN 1549-3652

(C) 2012 Science Publications

\title{
The Street Children Development in Open House
}

\author{
Didin Saripudin \\ Department of History Education, \\ Faculty of Social Studies Education, Indonesia University of Education, Indonesia
}

\begin{abstract}
Problem statement: The street children handling through open house has been developed in Indonesia since 1998. One of street children handling steps in open house is resocialization. This study is conducted to evaluate the effect of resocialization program implemention in open house on the street children and to determine how far such program reached its goal. Approach: The design of this study was program evaluation using quantitative approach. This study used Context, Input, Process and Product (CIPP) evaluation model by focusing on three of four components of CIPP evaluation model such as input, process and product. The population and sample of the study were administrator, facilitator and street children chosen from 16 open houses in Bandung City, West Java Province, Indonesia. Results: The perception of administrator, facilitator and street children on input relevance was positive in avarage level. The perception of administrator, facilitator and street children on process was positive in avarage and high level. This study also presents input and process variables contribute significantly toward the product variable. Conclusion/Recommendations: The street children resocialization program in open house in Bandung, from input, process and product components, is generally in average level, there are still some weaknesses that can be handled. In order to reach the goal of street children resocialization in open house, corrective action can be taken comprehensively and synergically by the responsible ones.
\end{abstract}

Key words: Development, resocialization, street children, open house

\section{INTRODUCTION}

There are about 150.000 street children in Indonesia spreaded in cities, especially big cities (Saripudin et al., 2008). Street children are children who spend most of his time to earn for money or walking through the street or other public places. Street children face the situation in which their rights are not fully fulfilled, from education aspect, life continuity, growth and protection (BKSN, 2000). The street children are susceptible to negative influences from environment in the street so most of them have social deviant.

The street children are often identified as free, wild children who do not want to be regulated and usually do negative actions such as stealing, fighting, drinking, using drugs, smelling glue, having free sex and etc. This condition happens due to strained relationship with parents. There are without control and attention in the street, even some of them are thrown out by their parents or they consciously leave their houses. Living without parent may make the children free to do everything. The influence of street and friends make their personality gradually adjust to the life of street people. The longer they live in the street, the stronger the influence on their attitude and behavior (Ahmad et al., 2008).
The efforts to protect, guide and recover their attitude and behavior to social norms are very important to do. In handling the street children, there are three general approaches that are street based, centre based and community based (DBKA, 1996; Silva, 1996). Handling the street children through open house has been developed in Indonesia since 1998, which is the model of street children handling by using such three approaches concurently. Since 1998 the open houses have been establishe throughout provinces, especially big cities.

The general aim of open house establisment is helping the street children in handling their problems and deciding the alternatives of their needs fulfillment. Specifically, the aims of open house establishment are (a) reconstructing children's attitude and behaviour according to the prevailed norm and values in commmunity, (b) trying to return the children to their houses, if it is possible, or take them to center and other representative institutions, if it is neede and (c) giving various service for children's needs fulfillment and preparing their future to be productive and independent citizens.

The effort of street children handling in open house follows there 5 stages, as described in following Fig. 1. 


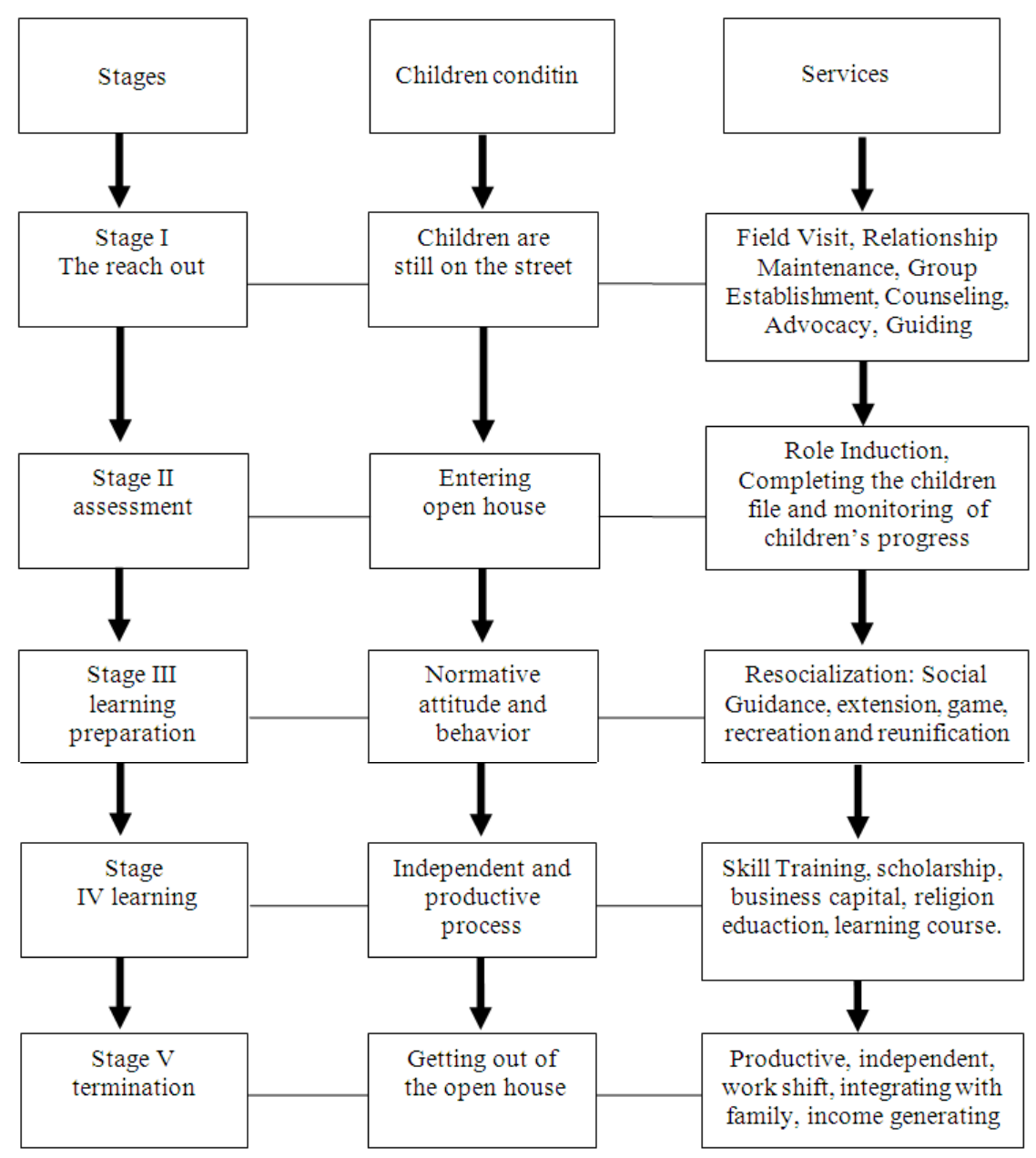

Fig. 1: Stages of Street Children Service Source: Adapted from DJBKS (1999)

One of important stages is learning preparation stage in which the street children follow resocialization, which is the effort to reconstruct their attitude and behavior based on social norm. Resocialization emphasizes the change of childrens' attitude and behavior. It should be done before other empowerment programs are given. Resocialization gives knowledge, awareness and strength of selfcompetence in facing daily life and solving the problem. Therefore, the aim of resocialization of street children in open house is to make the street children have good and positive attitude and life philosophy, present good social behavior, the competence to regulate themselves in handling life obstacle (BKSN, 2000).

In resocialization of street children, facilitators use friendship and equality principles. Although they are still young, their experience in the street has made them mature. Resocialization avoids instruction pattern and giving advices continuously in which the children are treted as objects. The street children are treated as subject of change on themselves. The prevailed principle is that facilitators cooperate with the street children, not work for the street children. Facilitators and street children discuss to formulate activities, give consideration and give them spirit of selected effort. In the end of resocialization, the street children are hoped to be able to help themselves (DJBKS, 1999; Saripudin et al., 2008).

Some activities in street children resocialization are, firstly, general/ daily social guidance consisting of daily attitude and behavior such as: individual cleanliness, table manner, health keeping, speech manner, literacy, religion, home cleanliness, parent relationship, peer relationship, neighbor relationship, work safety, role induction, recreation, discussion and teaching of social norms; secondly, case guidance is a guidance to handle difficulty in street children's life 
consisting of avoiding, decreasing and stopping smoking, drinking, using drugs, smelling glues, absent from school, fighting, stealing, hating and competing against parent and frinds. The street children resocialization is conducted every time, especially when there is a problem need a guidance. General/ daily guidance is done continually every time. Case guidance is done when the problem occurs and its handling time depends on the problem faced by the children, it may need short time or long time if the case is serious (DJBKS, 1999).

The methods used in street children resocialization are (1) individual sosial guidance, which is guidance of children individually or one by one, either for general or case guidance; (2) group social guidance, which is guidance conducted in group in giving materials/ information to all children or guidance for the children who have similar problem; (3) home visit, which is visiting and guiding children in their family and involving parent and other family members. Such guidance and learning use discussion technique, giving advice, socio drama, role playing, quiz and test. Giving reward and punishment, writing, story telling, giving motivation, advocacy, giving information, changing experience and sharing feeling.

The program of street children resocialization in open house has been startet since 1998. The roblem today is how far the implementation of resocialization program reaches its goal. In fact, the number of street children does not decrease significantly and street children's social deviant is still high. Based on such background, the evaluation of street children resocialization in open house is needed

Therefore, this study is conducted to evaluate the implementation of resocialization program in open house on the street children and decide how far such program reaches its goal. This study uses Context, Input, Process and Product (CIPP) evaluation model stated by Stufflebeam (1971). The focus of this evaluation is on three main components such as input, the implementation of street children resocialization in open house (process) and the goal reach (product).

The evaluation of street children resocialization in open house tries to answer there following study questions:

- How far is the input relevance for the implementation of street children resocialization in open house from the organizers', facilitators' and street children' perspective?

- How far is the process of implementation of street children resocialization in open house from the organizers', facilitators' and street children' perspective?
- How far does implementation of street children resocialization in open house reach its goal from the organizers', facilitators' and street children' perspective?

- Are there factors contributing the process of implementation of street children resocialization in open house?

The aim of this study is to evaluate the program of street children resocialization in open house all around Bandung, West Java province, Indonesia from input, process and product aspects based on CIPP evaluation model by Stufflebeam (1971). Input evaluation includes resocialization curriculum, facilitator's competence, street children, facilities and learning media aspects. Process evaluation includes guidance and learning, organizer, parent and Non Governmental Organization (NGO) involvement and program monitoring aspcets. Meanwhile, product evaluation includes street children having good and positive life philosophy and attitude, showing social behavior based on social values, selfregulating competence, competence to handle life difficulty. This evaluation is viewed from two aspects; first, how far the program is relevant with the street children's needs and second, evaluating how far such program reches its goal.

\section{MATERIALS AND METHODS}

The study method used is program evaluation. According to Singarimbun and Effendi (2008), evaluation study has been more well-known nowadays because various programs in society should be known their benefit. The principal question of this study is how far the goal stated in the initial program is reached or has the signs that it can be reached. There are various kinds of evaluation study models, in which Context, Input, Process and Product (CIPP) by Stufflebeam (1971) is used in this study by focusing on three of four CIPP evaluation model components, which are input, process and product.

Population and sampel of the study are organizers, facilitators and street children selected from 16 open houses in Bandung city, West Java province, Indonesia. Such open houses are divided based on six areas in Bandung city such as Bojonagara, Cibeunying, Karees, Tegallega, Ujungberung and Gedebage. The sample number selection is based on the table arranged by Krejcie and Morgan (1970). Based on organizer population of 40 people, the appropriate number is 36 people; the appropriate number of facilitator sample is 132 people from 200 people of facilitator population; and from 4526 people of street children population, the 


\section{J. Social Sci., 8 (2): 267-273, 2012}

appropriate number of street children sample is 354 people. Systematic random sampling is used to select respondents from 16 open houses in Bandung city.

The instrument used in this study is questionnaire. Three questionnaire sets are provided, Set 1 for organizers, Set 2 for facilitators and untuk fasilitator dan Set 3 for street children. Before conducting the study in field, questionnaire trials are conducted in four open houses in Bandung city with 100 respondents consisting of organizers, facilitators and street children. From the result of instrument (questionnaire) trials, the Alpha Cronbach reliability index for the three sets is 0.70-0.87. According to Thorndike (1997), alpha score of 0.6 may be accepted or rejected, it means that the gained alpha score from instrument trials proves that such instrument is reliable to be used. Questionnaire data is analyzed using descriptive statistic and inference such as frequency, percentage, mean, ANOVA and Multiple regression using SPSS for Windows version 12.

\section{RESULTS}

Curiculum, facilitators, street children, facilities and learning media are variables contained in input components of this study. Table 1 presents whole mean score for curriculum, facilitators, street children, facilities and learning media. Generally, the organizers, facilitators and street children have positive score in avarage level on curriculum, facilitators, street children, facilities and learning media.

The street children have more positive perception than facilitators and organizers. ANOVAs analysis is done to describe the difference of organizers', facilitators' and street children's perspective on curriculum, facilitator, street children, facilities and learning media. From such analysis, it can be concluded that there is significant difference among organizers', facilitators' and street children's perception in input relevance of street children resocialization program.

Guidance and learning, organizer, parents and NGO involvement, program monitoring are variables contained in process components. Table 2 presents the whole mean score of guidance and learning, organizer, parents and NGO involvement, program monitoring. Generally, the organizers, facilitators and street children have positive score in high level on parents and NGO involvement and program monitoring, avarage level on guidance and learning and organizer involvement.

The street children have more positive perception than organizers and facilitators. ANOVAs analysis is done to describe the difference of organizers', facilitators' and street children's perspectives on guidance and learning, organizer, parents and NGO involvement, program monitoring.
Table 1: The whole mean score of input relevance of street children resocialization in open house

\begin{tabular}{llll}
\hline Variable & $\begin{array}{l}\text { Mean } \\
\text { score }\end{array}$ & $\begin{array}{l}\text { Deviation } \\
\text { standard }\end{array}$ & Interpretation \\
\hline Curriculum & 3.22 & 0.60 & Avarage \\
Facilitator & 3.46 & 0.67 & Avarage \\
Street Children & 3.24 & 0.71 & Avarage \\
Facilities & 2.73 & 0.75 & Avarage \\
Learning Media & 3.18 & 0.94 & Avarage \\
\hline
\end{tabular}

Table 2: The whole mean score of street children resocialization program in open house implementation process

\begin{tabular}{llll}
\hline Variable & $\begin{array}{l}\text { Mean } \\
\text { score }\end{array}$ & $\begin{array}{l}\text { Deviation } \\
\text { standard }\end{array}$ & Interpretation \\
\hline Guidance and Learning & 3.48 & 0.65 & Average \\
Organizer involvement & 3.33 & 0.78 & Average \\
Parent and NGO involvement & 3.73 & 0.81 & High \\
Program Monitoring & 3.82 & 0.68 & High \\
\hline
\end{tabular}

Table 3: The whole mean score of street children resocialization in open house product

\begin{tabular}{llll}
\hline Variable & $\begin{array}{l}\text { Mean } \\
\text { score }\end{array}$ & $\begin{array}{l}\text { Deviation } \\
\text { standard }\end{array}$ & Interpretation \\
\hline $\begin{array}{l}\text { Good Life Philosophy and Attitude } \\
\text { Presenting social attitude }\end{array}$ & 3.29 & 0.60 & Average \\
$\begin{array}{l}\text { based on social norms } \\
\text { Self-regulating competence }\end{array}$ & 3.71 & 0.58 & High \\
Competence to handle life difficulty & 3.23 & 0.68 & $\begin{array}{l}\text { Average } \\
\text { Average }\end{array}$ \\
\hline
\end{tabular}

From such analysis, it can be concluded that there is significant difference of organizers', facilitators' and street children's perspectives in the process of street children resocialization implementation.

The good and positive life philosophy and attitude based on social norms, self-regulating competence and competence to handle life difficulty are variables contained in product component. Table 3 presents the whole mean score of good life philosophy and attitude, presenting social behavior, self-regulating competence and competence to handle life difficulty. Generally, organizers, facilitators and street children have positive score in high level on presenting social behavior according to social norms, average level on good and positive life philosophy and attitude, self-regulating competence and competence to handle life difficulty.

The street children have more positive perception than facilitators and organizers. ANOVAs analysis is done to describe the perspective difference on good life philosophy and attitude, presenting social attitude, selfregulating competence and competence to handle life difficulty. From such analysis, it can be concluded that there is significant difference among the organizers', facilitators' and street children's perception on the product of street children resocialization program.

Multiple regression analysis is used to determine the correlation sinificance and independent variable contribution on dependent variable. In determining independent variable contributing to the process of program implementation, independent variables consist 


\section{J. Social Sci., 8 (2): 267-273, 2012}

of curriculum, facilitator, street children, facilities and learning media. Variables of program implementation are dependent variables that consist of guidance and learning, organizer, parent and society involvement and program monitoring.

Independent variables such as curriculum, facilitator, street children, facilities and learning media contribute by $34 \%(0.34)$ to guidance and learning, by $27 \%(0.27)$ to organizer involvement, by $21 \%(0.21)$ to parent and NGO involvement and by $37 \%$ (0.37) to program monitoring.

In determining independent variables contributing to program product, independent variables consist of curriculum, facilitators, street children, facilities, learning media, guidance and learning, organizer involvement, parent and society involvement and program monitoring. Variables of program product included in dependent variables consist of good and positive life philosophy and attitude, presenting social attitude based on social norms, self-regulating competence and competence to handle life difficulty.

Independent variables such as curriculum, facilitator, street children, facilities, learning media, guidance and learning, organizer involvement, parent and NGO involvement and program monitoring contribute by $58.40 \%(0.584)$ to good and positive life philosophy and attitude, by $43 \%(0.43)$ to presenting social attitude based on social norms, by $55.50 \%$ (0.555) to self-regulating competence and by $38 \%$ (0.38) to competence to handle life difficulty.

\section{DISCUSSION}

The study finding shows that the curriculum of street children resocialization program in open house is conducted based on the guide of Indonesia Republic Social Department. Such curriculum consists of core guidance and learning that will be performed. Curriculum should be explained by facilitator based on the street children's needs. Therefore, curriculum should be flexible containing the street children's needs and competence. According to Sudjana (2001), nonformal education curriculum such as street children resocialization program should be flexible so it can fulfill different program participants' needs. From the facilitator's skill aspect, it shows that facilitators in open houses in Bandung consist of facilitators having knowledge and skill in developing street children. Most of facilitators $(89 \%)$ have education background of minimum Sekolah Menengah Pekerja Sosial (SMPS) or Social Worker High School. It is in line with BKSN (2000) requiring that minimum education of facilitators in open houses is SMPS graduate. The task given to facilitators is adequate and appropriate with practical knowledge they have. It still needs special practice, workshop or seminar routinely to improve facilitators' knowledge and skill.

The street children have different background, in which generally they have social deviance, either the light or serious problem. Generally, they need resocialization program in open house. According to Dewi (2004), the effort to reconstruct their attitude and behavior based on social norms are very imprtant to do through resocialization activity. From the facility aspect, open houses in Bandung has generally been adequate in minimum level. According to Sudjana (2006), facility will determine the success of process and output of non-formal education program. If the facility is not adequate, it will block and decrease the success of non-formal education program. From learning media aspect, it shows that media (printed and electronic) in open houses in Bandung has been adequate in minimum level. This finding is in line with the study finding of Ishak (2000) presenting that learning media is still lack and needs to be added. The existing media has been old and should be replaced.

The study finding shows that guidance and learning is done through social and mental guidance in which the street children are directed based on their needs. This finding is in line with BKSN (2000) that in street children resocialization, the facilitators use friendship and equality prinsiples. Although they are still young, theis experience in the street has made them mature. The street children are treated as subject of change on them. Organizers involve in all stages of street children resocialization program in open house. This finding is in line with the study finding of Dewi (2004) that planning, organizing, implementation and monitoring functions are very important to do by the organizers if they want the street children resocialization program successful. Parent involvement is usually by inviting the street children's parents or the members of family to come to open house. The facilitators or organizers usually come to their houses (home visit). This finding supports the study finding of Sulistiati (2001) presenting that the important factor in the success of street children development is parent involvement in such program. Street children development should not be separated from the effort to develop their family as well.

Program monitoring is very important to ensure that street children resocialization program in open house can be implemented as it is planned. DSPJ (2001) states the importance of program monitoring in which program monitoring is an activity to guide and direct the administrator of open house about the process 
and daily tasks, either in official administration or service administration.

The study finding presents that there is perception difference among the organizers, facilitators and street children about the good and positive life philosophy and attitude, presenting social behavior based on social norms, self-regulating competence and competence to handle life difficulty. It describes that there is a space in order to make the open houses improve their input quality and process of street children resocialization program in open house. This finding is quite agreed with Dewi (2004) study finding showing that there is a change in most of street children after following program in open house in matters of awareness of education importance for their future, the growth of their self-confidence and well-manner. It is also supported by the study finding of Ishak (2000) presenting that the street children following the program in open house has been able to solve the problems they face. If they can solve it by themselves, they need the role of parent, relatives, teacher or facilitator to help them in solving their problems.

The street children resocialization program in open houses in Bandung city still have problems. The main problems are first, limited learning facilities; second, limited available fund; third, the family of street children is very poor; forth, the number of facilitators to guide the street children is lack; fifth, the expert helping to solve the problems faced by street children are still lack; and sixth, the follow-up of program participant placement for the participants who do not have home and family in order to make them return to the street. These study findings are agreed with Sudrajat (1998) study that the budget for street children development is still less and still depends on the budget of Indonesia's Social Department. In Bandung city, the budget to handle street children is very low. Sugiarta (2002) stated in his study that a lot of street children development programs have been implemented but the human resources and facilities aspects are not prepared optimally so that the program is not running well.

\section{CONCLUSION}

Referring to the questions of study, it can be concluded that: The organizers', facilitators' and street children's perception on input relevance such as curriculum, facilitator, street children, facilities and learning media is positive in avarage level, but the street children have more positive perception than facilitators and organizers. Besides that, there is significant difference among the facilitators', organizers' and street children's perception on curriculum, facilitator, street children, facilities and learning media.

The organizers', facilitators' and street children's perception on the process of street children resocialization program in open house has positive score in high level toward parent and LSM involvements and program monitoring. Meanwhile, it is in avarage level toward guidance and learning and organizer involvement. The street children have more positive perception than facilitators and organizers. Besides that, there is significant difference among the facilitators', organizers' and street children's perception on guidance and learning, organizer, parent and NGO involvements and program monitoring.

The organizers', facilitators' and street children's perception on the product of street children resocialization program in open house has positive score in high level for presenting social behavior based on social norms, in avarage level for good and positive life philosophy and attitude, self-regulating competence and competence to handle life difficulty. Besides that, there is significant difference among the facilitators', organizers' and street children's perception on good and positive life philosophy and attitude, presenting social behavior, self-regulating competence and competence to handle life difficulty.

This study finding also shows that curriculum, facilitator, street children, facilities and learning media give significant contribution to guidance and learning, organizer, parent and NGO involvements and program monitoring. Curriculum, facilitator, street children, facilities, learning media, guidance and learning, organizer, parent and NGO involvements and program monitoring give significant contribution to the good and positive life phylosophy and attitude, presenting social behavior, self-regulating competence and competence to handle life difficulty.

Based on the findings, it shows that street children resocialization program in open house in Bandung city is generally in avarage level for input, process and product aspects. There are some weaknesses that should be solved. Therefore, in order to reach the goal of street children resocialization program in open house, corrective actions should be taken comprehensively and synergically by all responsible ones.

\section{ACKNOWLEDGEMENT}

This research is a grant from the Directorate General of Higher Education, Indonesia Ministry of Education. The author would like to express their sincere appreciation for all of the support provided. 


\section{REFERENCES}

Ahmad, A.R., R.A. Latif and D. Saripudin, 2008. Masyarakat dan pendidikan: Perspektif sosiologi. National Library Malaysia.

BKSN, 2000. Pedoman Penyelenggaraan Peningkatan Kesejahteraan Sosial Anak Jalanan Melalui Rumah Singgah. 1st Edn., Deputi tsb., Jakarta, pp: 69.

DBKA, 1996. Petunjuk Teknis Pelaksanaan Bimbingan dan Pembinaan Kesejahteraan Sosial Keluarga Melalui Asistensi Keluarga. 1st Edn., Departemen Sosial RI, Jakarta, pp: 51.

Dewi, E.A.S., 2004. Laporan Penelitian Efektifitas Manajemen Sistem Pembinaan Anak Jalanan di Kota Bandung Tahun. 1st Edn., Fakultas Ilmu Komunikasi, Bandung, pp: 48.

DJBKS, 1999. Pedoman Penyelenggaraan Pembinaan Anak Jalanan Melalui Rumah Singgah. 1st Edn., Departemen Sosial RI, Jakarta, pp: 103.

DSPJ, 2001. Pelayanan kesejahteraan sosial anak terlantar dan anak jalanan di jawa barat. Proceedings Conference on Anak Jalanan dan Anak Terlantar di Jawa Barat, (AJATJB' 01), Dinas Sosial Jabar, Bandung.

Ishak, M., 2000. Pengembangan model program pendidikan taruna mandiri. Studi Terfokus Pada Kehidupan Anak-Anak Jalanan di Bandung, Bandung.

Krejcie, R.V. and D.W. Morgan, 1970. Determining sample size for research activities. Educ. Psychol. Measurement, 30: 607-610. DOI: $10.1177 / 001316447003000308$

Saripudin, D., A. Suwirta and K. Komalasari, 2008. Resocialization of street children at open houses: A case study in the city of Bandung, Indonesia. J. Educare., 1: 91-102.
Silva, T.L., 1996. Community mobilization for the protection and rehabilitation of street children. Proceedings International Conference on Street Children, (ICSC' 96), Departemen Sosial Republik Indonesia, Indonesia.

Singarimbun, M. and S. Effendi, 2008. Metode penelitian survei. LP3ES, Jakarta.

Stufflebeam, D.L., 1971. The relevance of the CIPP evaluation model for educational accountability. J. Res. Dev. Educ., 5: 19-25.

Sudjana, D., 2001. Pendidikan Luar Sekolah: Wawasan, Sejarah Perkembangan, Falsafah and Teori Pendukung, Serta Asas. 3rd Edn., Falah Production, Bandung, ISBN: 979960950X, pp: 401.

Sudjana, D., 2006. Evaluasi program pendidikan luar sekolah untuk pendidikan nonformal dan pengembangan sumber daya manusia. Bandung: Remaja Rosdakarya, Jakarat.

Sudrajat, T., 1998. Rumah singgah anak jalanan suatu praktek pekerjaan sosial. Departement Sosial Republik Indonesia, Jakarta.

Sugiarta, A.N., 2002. Profil rumah singgah dalam menyiapkan anak jalanan yang produktif dan mandiri. M.Ed. Thesis, Indonesia University of Education.

Sulistiati, 2001. Model pendekatan terpadu untuk memecahkan masalah anak rawan. Studi Pengembangan Model Implemetasi PIPS di Masyarakat.

Thorndike, R.M., 1997. Measurement and Evaluation in Psychology and Education. 6th Edn., Merrill, New Jersey, ISBN: 0132541785, pp: 583. 